\title{
Interleukin 7 Measurement
}

National Cancer Institute

\section{Source}

National Cancer Institute. Interleukin 7 Measurement. NCI Thesaurus. Code C74835.

The determination of the amount of interleukin 7 present in a sample. 